\title{
Sex, receptors, and attachment: a review of individual factors influencing response to oxytocin
}

\section{Kai S. MacDonald *}

Department of Psychiatry, University of California Medical Center, San Diego, CA, USA

\section{Edited by:}

Idan Shalev, Duke University, USA

Reviewed by:

René Hurlemann, University of Bonn, Germany

Benjamin A. Tabak, University of

California Los Angeles, USA

\section{*Correspondence:}

Kai S. MacDonald, Department of Psychiatry, UCSD Medical Center,

200 West Arbor Drive, San Diego, CA

92103-8216, USA.

e-mail: kaismacdonald@me.com
As discussed in the larger review in this special issue (MacDonald and Feifel), intranasal oxytocin (OT) is demonstrating a growing potential as a therapeutic agent in psychiatry. Importantly, research suggests that a variety of individual factors may influence a person's response to OT. In this mini-review, I provide a review of three: (1) sex and hormonal status; (2) genetic variation in aspects of the OT system (i.e., OT receptors); and (3) attachment history. Each of these factors will be important to monitor as we strive to develop a richer understanding of OT's role in human development, brain-based disease, and the potential for individualized, OT-targeted treatments.

Keywords: oxytocin, sex factors, attachment, oxytocin receptor gene, CD38/ADP-ribosyl cyclase activity

\section{INTRODUCTION}

Aside from a wide range of drug-specific factors (discussed in MacDonald and Feifel in this special edition), several individual factors may influence a person's response to oxytocin. Three of these factors are reviewed below.

\section{SEX AND HORMONAL STATUS}

The central OT system acts as but one component of a complex neurochemical milieu in which gonadal steroids also play a significant part. As extensively discussed in recent full-length reviews, gonadal steroid hormones (i.e., estrogen, progesterone, and testosterone), and the two nonapeptides - OT and arginine vasopressin (AVP) - coevolved, all playing a vital role in mammalian social development through their unique influence on parental bonding, mate choice, and attachment (van Anders et al., 2011; Bos et al., 2012). In toto, there is substantial evidence indicating that at least some of oxytocin's effects are correlated with an individual's sex, in part via the influence of gonadal hormones. We can only give this important topic brief review, and direct the reader to more comprehensive treatments (van Anders et al., 2011; Bos et al., 2012; Gabor et al., 2012).

As background, animal studies indicate that sex-specific differences in response to OT are common (Williams et al., 1994; Cho et al., 1999; Bales and Carter, 2003; Bales et al., 2007), and the histological structure for OT neurons is sexually dimorphic, suggesting that sex steroids play a role in early morphogenesis of this system (de Vries, 2008). Estrogen upregulates OT and OT receptor (OTR) production (Patisaul et al., 2003; Windle et al., 2006; Choleris et al., 2008), whereas testosterone promotes both OTR binding in the hypothalamus (Johnson et al., 1991) as well as production of AVP (Delville et al., 1996), which has many opponent actions to OT (Neumann and Landgraf, 2012). In humans, moreover, testosterone seems from one perspective to have opposite behavioral effects to the prosocial impact classically associated with OT: decreasing trust, generosity, empathy (van Honk and Schutter, 2007; Zak et al., 2009; Bos et al., 2010), though more recent conceptualizations of the parochial, "us vs. them" aspect of OT make this picture more complex, and evidence OT's "darker" side (Shamay-Tsoory et al., 2009; De Dreu et al., 2010, 2011, 2012; Declerck et al., 2010). Though OT is only one small piece of the complex psychobiology of gender, some have posited different OT-biased relational strategies for the sexes, with females more prone to "tend and befriend" (Taylor et al., 2000; but, see Smith et al., 2012b), whereas more warrior-prone, hierarchybound males "compete and defeat" (David and Lyons-Ruth, 2005; Smeets et al., 2009; Van Vugt, 2009; Gabor et al., 2012).

More evidence for sex-specific differences in the OT system come from research indicating that men and women show differences in plasma OT levels (Ozsoy et al., 2009; Gordon et al., 2010; Holt-Lunstad et al., 2011; Weisman et al., 2012b), as well as gender-specific behavioral correlations with OT (Gordon et al., 2010; Zhong et al., 2012; but, see Szeto et al., 2011 for critique of plasma OT measurement techniques). Coming from the perspective of genetic variations in nonapeptide receptors, Walum et al. (2012) have found an association between the OTR variant rs7632287 and pair-bonding behaviors in women but not in men, whereas an earlier study found an association of an AVP receptor polymorphism and pair-bonding in men but not women (Walum et al., 2008). Furthermore, numerous studies in the growing OTR literature note sex-specific associations between genetic variants in the OTR gene and personality characteristics (Stankova et al., 2012), neural responses to emotionally salient cues (Tost et al., 2010), hypothalamic gray matter volume (Tost et al., 2010), and empathy (Wu et al., 2012), though other studies in this area have failed to find a sex bias (Rodrigues et al., 2009; Saphire-Bernstein et al., 2011; Feldman et al., 2012). A final set of salient investigations found that amygdala-prefrontal cortical connectivity - which can be impacted by OT in normal subjects (Sripada et al., 2012) and anxiety patients (Labuschagne et al., 2011) - may be related in a gender-specific way to the development of anxiety and depressive disorders (Burghy et al., 2012), both putative clinical targets for intranasal oxytocin 
(IN OT) (Slattery and Neumann, 2010; Neumann and Landgraf, 2012).

Focusing on clinical OT trials using IN OT, gender-dependent effects have been demonstrated in some single-dose studies (Hurlemann et al., 2010), including studies of effects on they amygdala (Domes et al., 2010; Rupp et al., 2012), and interpersonal behavior (Liu et al., 2012) but - consistent with the variability in this literature - many other single-dose studies have not found an effect of sex (see Bartz et al., 2011b for review). A recently investigated individual factor at least partly related to sex (due to different sexual selection strategies between males and females; Ihara and Aoki, 1999) is the relationship status of the person receiving the drug. Specifically, Scheele et al. (2012) found in a group of 86 normal heterosexual males that IN OT preferentially stimulated men in a monogamous relationship - but not single males - to maintain more personal space from women (but not men). Whether these effect would cross over to females and same-sex relationships in interesting and unexplored.

Though the suggestion of gender effects in single-dose studies of normal subjects may be informative, as discussed in the accompanying larger review (MacDonald and Feifel), these results do not speak directly to the clinical question of whether sex differences moderate the effects of chronic OT treatment in clinically ill populations. The first study to intimate such a sex moderation effect was a randomized, double-blind, within-subjects crossover study of OT (40 IU BID for 3 weeks) in patients with generalized anxiety disorder (GAD) (Feifel et al., 2011). This trial demonstrated a trend level dose-by-gender effect such that males treated with OT showed a significant clinical improvement in HAM-A scores with OT, whereas females showed higher HAM-A scores during 3 weeks of treatment. The three extant studies using multiple weeks of OT treatment in patients with schizophrenia demonstrated a male bias in recruitment ( 62 males treated vs. 13 females), though none showed a sex-by-drug effect (Feifel et al., 2010; Pedersen et al., 2011; Modabbernia et al., 2012). Notable in this context are studies by Rubin et al. $(2010,2011)$ indicating that female but not male patients with schizophrenia show a correlation between plasma OT concentrations, perception of facial emotion expression, and psychopathology, as well as evidence that women with borderline personality disorder have reduced plasma OT levels, even after controlling for hormonal factors (Bertsch et al., 2012).

In terms of future clinical studies with IN OT, the abovementioned sex-specific variables may have at least two repercussions. First, they highlight the importance of monitoring/measuring hormone levels, menstrual phase, and oral contraceptive status in trials with IN OT, given these parameters may impact OT levels (Salonia et al., 2005, but, see Rubin et al., 2011) and psychiatric symptoms (Rubin et al., 2010). Secondly, given that there are sex differences in the incidence of many of the disease states for which OT is a putative treatment (i.e., autism, postpartum depression), further delineation of the role of sex in the effects of chronic OT treatment will be critical.

\section{NEUROPEPTIDERGIC INDIVIDUALITY: GENETIC VARIATIONS IN OTR AND CD38}

Aside from sex, a second individual factor of import in relation to IN OT treatment involves phenotypically relevant individual genetic variations within different aspects of the OT system (Kumsta and Heinrichs, 2012), what one could call "neuropeptidergic individuality." This term is annexed from - and a subset of - what Cravchik has called "neurochemical individuality": genetically determined factors that underlie individual differences in brain function. Exemplars include variations in aspects of the major neurotransmitter systems (i.e., dopamine, serotonin) (Cravchik and Goldman, 2000).

In terms of OTs part in "neuropeptidergic individuality," a recent, rapidly expanding body of literature indicates that genetic differences in aspects of the functional OT system (the OTR itself and the ectoenzyme CD38, which contributes to OT secretion) (Figure 1) contribute to measurable aspects of an individual's personality (Kumsta and Heinrichs, 2012). Though the specific cellular and functional consequences of these genetic variations have not been fully explicated, a convergent picture of their phenotypic consequences is emerging, indicating that in neurotypical subjects, genetic differences in the OT system impacts positive personality factors and social behavior (Bakermans-Kranenburg and van Ijzendoorn, 2008; Rodrigues et al., 2009; Montag et al., 2011; Saphire-Bernstein et al., 2011; Walter et al., 2012), differential responses to stress and maltreatment (Kim et al., 2010; Bradley et al., 2011; Chen et al., 2011b; Thompson et al., 2011; Brune, 2012; Norman et al., 2012), brain anatomy (Inoue et al., 2010; Furman et al., 2011), and differences in the function of stress and emotionrelated brain areas (Tost et al., 2010; Love et al., 2012). Moreover, genetic variation in the OT system has been implicated in several of the disease states where OT has shown the most therapeutic promise: schizophrenia (Teltsh et al., 2011; Montag et al., 2012) and autism (Ebstein et al., 2012).

Though no published studies have examined the role of genetic variation in the OT system to a psychiatrically ill person's clinical response to OT, several recent studies in normal subjects indicate that we should be alert for such effects. For example: subjective responses to infant's faces were moderated by the (rs53576G) allele of the OTR (Marsh et al., 2012); there is an association between several genetic variations in the OTR (rs53576, rs2254298, rs2228485) and performance on the Reading the Mind in the Eyes Test (RMET) (Lucht et al., 2012); and the OXTR (rs2268498) polymorphism modulated neural responses to emotional faces (O'Connell et al., 2012). Moreover, as evidence of the overlap between central dopaminergic and oxytocinergic systems, female OTR (rs4813625) carriers demonstrated greater stress-induced dopamine release, higher attachment and trait anxiety, and lower emotional well-being scores (Love et al., 2012).

A relatively new component of the central OT system - but one which is rapidly galvanizing interest - is the transmembrane enzyme CD38, whose role was discovered by observing the social behavior of CD38 knock-out mice. These socially hapless mice forget the location of their pups as well as previous social encounters, and synthesize, but don't properly secrete OT. Notably, these behavioral and hormonal deficits are restored with either (a) viral transfection of a functional CD38 gene or (b) exogenous OT (Jin et al., 2007). In humans, variants in the CD38 gene have been tied to OT secretion (Kiss et al., 2011), social processing (Higashida et al., 2012a; Sauer et al., 2012), sensitive parenting (Feldman, 2012), and potentially autism (Higashida et al., 2011, 2012b for review). 


\section{Individual Parameters That May Impact Response to OT}

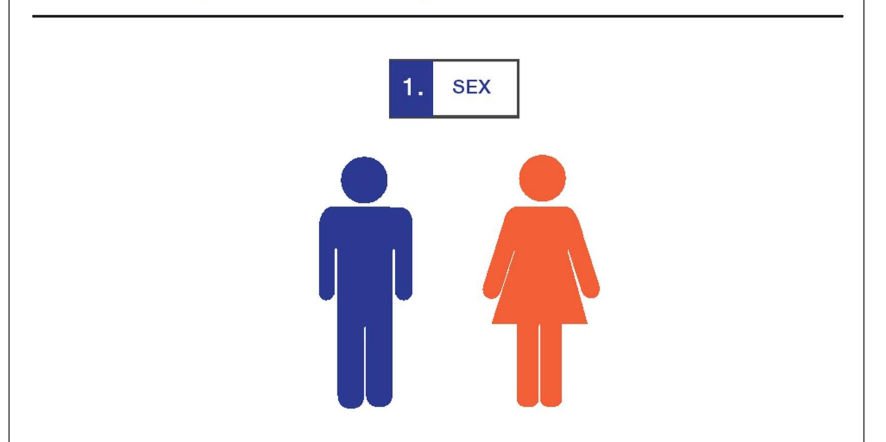

Oxytocin Receptor/CD38 Subtype

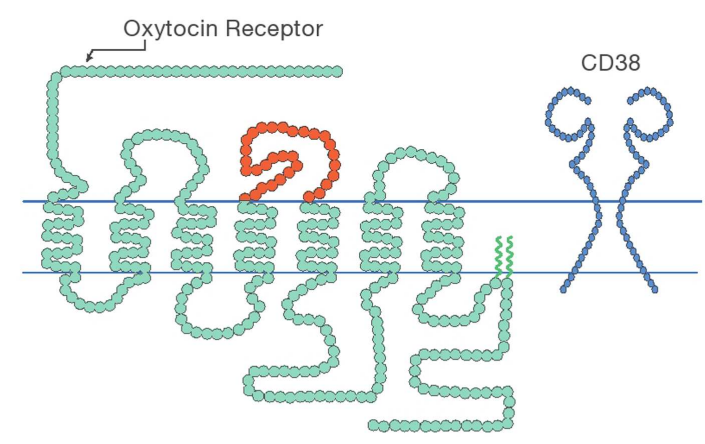

3. Early Attachment Experiences

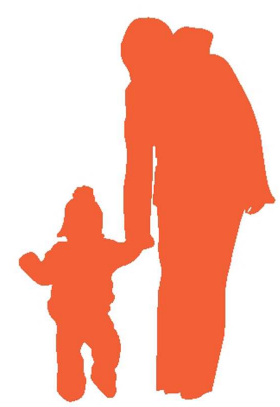

FIGURE 1 |Three individual factors which mediate response to oxytocin are (1) sex and hormonal status; (2) genetic variations in the oxytocin receptor and CD38 system; and (3) early attachment experiences. The extent to which these factors play a role in a person's response to oxytocin-targetted therapeutics for brain-based disease requires further exploration (see MacDonald and Feifel in this special section).

Similarly to the OTR studies above, a recent imaging genetics study in neurotypical males suggested that variation in the CD38 gene influenced behavioral and neuronal measures of social processing and amygdala response to IN OT (Sauer et al., 2012). A clinical point of interest in this context is that retinoids (vitamin-A related compounds) can be used to increase CD38 expression (Riebold et al., 2011), thus providing an alternative way to stimulate the OT system or potentially augment IN OT treatment (Ebstein et al., 2011).

Though the focus here is only on variation in the OTR and CD38 gene, other potential contributors to neuropeptidergic individuality include: (1) differences in baseline and dynamic levels of OT release in the brain and/or secretion into the plasma, the latter found to correlate with personality and brain structure (Andari et al., 2012); as well as (2) differences in regional OTR and AVPR receptor density, a factor which influences the social behavior of rodents (Hammock and Young, 2006; Ross et al., 2009; Ophir et al., 2012). Though a few studies have examined postmortem OTR density in the human CNS (Loup et al., 1989, 1991), as mentioned in the accompanying review (MacDonald and Feifel), synthesis of a small-molecule radioligand for the OTR (Smith et al., 2012a), would greatly facilitate our understanding of the role of OTR density and location in living humans.

Of critical import in the field of psychiatric genetic association studies are the issues of replicability and effect size (discussed at length in Gershon et al., 2011; Ebstein et al., 2012). For example, in contrast to several of the positive associations noted above, studies have failed to find associations between genetic variations in the OTR and prosocial behavior in the trust or dictator game (Apicella et al., 2010), optimism (Cornelis et al., 2012), and autism (Tansey et al., 2010). Replication studies and larger sample sizes in a variety of populations using different varieties of associations (i.e., different combinations of haplotypes) (Yamasue et al., 2012) are therefore necessary to more fully explore and quantify the strength of the abovementioned associations.

Returning to the clinical implications of neuropeptidergic individuality, it is possible that individual variation in aspects of the OT system may in the future be thought of as clinicians currently conceptualize individual variations in dopamine and serotonin systems. One brings to mind the association of DRD4 variants with approach-related traits (Munafo et al., 2008) and response to dopaminergic medication (Hamarman et al., 2004), or the association of serotonin receptor polymorphisms with susceptibility to adverse clinical outcomes (van Ijzendoorn et al., 2012), as well as response to serotonergic antidepressants (Mrazek et al., 2009). Aside from its import in terms of understanding individual variability in both neurotypical and clinically ill populations, neuropeptidergic individuality may have implications in terms of psychiatric pharmacogenetics: the use of information about individual's genotype in the selection of psychiatric treatment (Malhotra et al., 2007). Though this approach is currently speculative in terms of OT, it has growing clinically relevance for antidepressants (McMahon et al., 2006) and antipsychotics (Zhang et al., 2010). Looking forward, large clinical trials are needed to investigate the possibility that genetic variations in the abovementioned aspects of the OT system may influence clinical response to OT treatment. That said, the decreasing cost and increasing efficiency of gene sequencing technologies, coupled with larger clinical trials of clinical use of OT (ClinicalTrials.gov), will certainly inform the relevance of this proposed genotypeinformed treatment. Moreover, identification of "OT sensitive" 
phenotypes may optimize patient selection for treatment and trials.

\section{EARLY EXPERIENCE, EPIGENETICS, AND NEUROPLASTICITY}

In addition to abovementioned genetically determined factors, a third influence on a person's response to IN OT concerns the way that that an individual's unique attachment history has sculpted the function of their OT system (Gordon et al., 2011; Bales and Perkeybile, 2012). More specifically, convergent translational and developmental research in a variety of fields indicates that the central OT system is similar to the HPA axis in being an environmentally influenced plastic brain system whose function is directly and perhaps permanently impacted by early experience (Gunnar and Quevedo, 2008; Brune, 2012; McCrory et al., 2012). Clinically, it is clear that maladaptive early experiences impact the "phenotype" of several psychiatric disorders that may benefit from IN OT, including depression (Saveanu and Nemeroff, 2012) and schizophrenia (Read and Hammersley, 2005; van Os et al., 2010). Recent imaging studies indicate that early adversity impacts brain systems of import to both psychiatric disease and OT treatment (i.e., amygdala and hippocampus; Dannlowski et al., 2012; Teicher et al., 2012).

Research on the environmental plasticity of the OT system began with sentinel animal research indicating intergenerational transmission of behavior in more- and less-attentive rat mothers (Champagne and Meaney, 2001; Champagne et al., 2001; Meaney, 2001). Some of these changes, notably, are mediated via epigenetic modulation of the OT system (Cushing and Kramer, 2005; Stolzenberg et al., 2012). More recently, human experiments support the hypothesis that dynamic changes in components of the OT system (i.e., methylation of the OTR gene; Jack et al., 2012; Unternaehrer et al., 2012) and possibly neurodevelopmental changes in OT sensitive brain structures (see Andari et al., 2012 for discussion) are some of the proximate effectors through which early parental care impacts an individual throughout life (Champagne et al., 2001; Champagne, 2008; Gordon et al., 2011; Bales and Perkeybile, 2012 for reviews). Other convergent evidence comes from attachment-informed behavioral research which indicates parallels and reciprocal influence between parental and infant OT levels and the species-specific behaviors associated with secure attachment and optimal psychosocial development (Feldman, 2012). As mentioned above, these factors appear to be influenced by both genetic variations in the OT system and by IN OT (Naber et al., 2010, 2012; Weisman et al., 2012a).

\section{REFERENCES}

Andari, E., Schneider, F. C., Mottolese, R., Vindras, P., and Sirigu, A. (2012). Oxytocin's fingerprint in personality traits and regional brain volume. Cereb. Cortex. doi: 10.1093/cercor/bhs328. [Epub ahead of print].

Apicella, C. L., Cesarini, D., Johannesson, M., Dawes, C. T., Lichtenstein, P., Wallace, B., et al. (2010). No association between oxytocin receptor (OXTR) gene polymorphisms and experimentally elicited social preferences. PLOS ONE 5:e11153. doi:10.1371/journal.pone. 0011153

Bakermans-Kranenburg, M. J., and van Ijzendoorn, M. H. (2008). Oxytocin receptor (OXTR) and serotonin transporter (5-HTT) genes associated with observed parenting. Soc. Cogn. Affect. Neurosci. 3, 128-134.

Bakermans-Kranenburg, M. J., van Ijzendoorn, M. H., Riem, M.

Focusing specifically on the OT treatment literature, several studies indicate that aversive early attachment experiences and attachment style impact stress systems, CSF, and plasma OT levels (Heim et al., 2009; Strathearn et al., 2009, 2012; Bertsch et al., 2012; Weisman et al., 2012a) as well as later response to IN OT (Huffmeijer et al., 2011, 2012; Simeon et al., 2011; van Ijzendoorn et al., 2011; Bakermans-Kranenburg et al., 2012; Pierrehumbert et al., 2012). For example, neurotypical patients' generosity in response to IN OT is moderated by parental love-withdrawal (Huffmeijer et al., 2012), and patients with aversive early attachment representations had a negative response to IN OT compared to those with more positive representations (Bartz et al., 2010). Other literature suggests that variation in the OT system may mediate gene-environment interactions between early adversity and outcomes (Kim et al., 2010; Bradley et al., 2011; Chen et al., 2011a; Thompson et al., 2011).

In toto, data reviewed here support the hypothesis that an individual's early attachment experiences - carried forward in OT-responsive neural networks and the dynamic function of the central OT system - may impact a person's response to IN OT. To date, in keeping with the general trend noted throughout this and the accompanying larger review (MacDonald and Feifel, this issue) the evidence that early experience impacts OT response in clinical populations is sparse. The only published study in this area demonstrated that patients with borderline personality disorder and anxious attachment showed less trust than those with more secure attachment after IN OT (Bartz et al., 2011a). Despite the overall lack of studies of IN OT in patient groups, the findings cited above suggest that clinical trials examining putative therapeutic effects of OT will be wise to include an assessment of attachment style and early trauma as individual factors that may influence response to OT.

\section{CONCLUSION}

Given the paucity of clinical trials with IN OT, the suggestion that the above factors may be moderators of clinical response to IN OT should be viewed with circumspection. Both larger-scale therapeutic trials with IN OT as well as investigations of the role of aspects of the central OT system in different disease states will be necessary to determine their ultimate clinical and therapeutic relevance.

\section{ACKNOWLEDGMENTS}

Thanks to Bruce Ammons for editorial suggestions and Maribel Santos for the illustration. Some of the author's work is supported by the Goodenough Neuroscience Research Fund.

M., Tops, M., and Alink, L. R. (2012). Oxytocin decreases handgrip force in reaction to infant crying in females without harsh parenting experiences. Soc. Cogn. Affect. Neurosci. 7, 951-957.

Bales, K. L., and Carter, C. S. (2003). Sex differences and developmental effects of oxytocin on aggression and social behavior in prairie voles (Microtus ochrogaster). Horm. Behav. 44, 178-184.
Bales, K. L., and Perkeybile, A. M. (2012). Developmental experiences and the oxytocin receptor system. Horm. Behav. 61, 313-319.

Bales, K. L., Plotsky, P. M., Young, L. J., Lim, M. M., Grotte, N., Ferrer, E., et al. (2007). Neonatal oxytocin manipulations have longlasting, sexually dimorphic effects on vasopressin receptors. Neuroscience 144, 38-45.

Bartz, J., Simeon, D., Hamilton, H., Kim, S., Crystal, S., Braun, A., et al. 
(2011a). Oxytocin can hinder trust and cooperation in borderline personality disorder. Soc. Cogn. Affect. Neurosci. 6, 556-563.

Bartz, J. A., Zaki, J., Bolger, N., and Ochsner, K. N. (2011b). Social effects of oxytocin in humans: context and person matter. Trends Cogn. Sci. (Regul. Ed.) 15, 301-309.

Bartz, J. A., Zaki, J., Ochsner, K. N., Bolger, N., Kolevzon, A., Ludwig, N., et al. (2010). Effects of oxytocin on recollections of maternal care and closeness. Proc. Natl. Acad. Sci. U.S.A. 107, 21371-21375.

Bertsch, K., Schmidinger, I., Neumann, I. D., and Herpertz, S. C. (2012). Reduced plasma oxytocin levels in female patients with borderline personality disorder. Horm. Behav. doi: 10.1016/j.yhbeh.2012.11.013. [Epub ahead of print].

Bos, P. A., Panksepp, J., Bluthe, R. M., and Honk, J. V. (2012). Acute effects of steroid hormones and neuropeptides on human social-emotional behavior: a review of single administration studies. Front. Neuroendocrinol. 33, 17-35.

Bos, P. A., Terburg, D., and van Honk, J. (2010). Testosterone decreases trust in socially naive humans. Proc. Natl. Acad. Sci. U.S.A. 107, 9991-9995.

Bradley, B., Westen, D., Mercer, K. B., Binder, E. B., Jovanovic, T., Crain, D. F., et al. (2011). Association between childhood maltreatment and adult emotional dysregulation in a lowincome, urban, African American sample: moderation by oxytocin receptor gene. Dev. Psychopathol. 23, 439-452.

Brune, M. (2012). Does the oxytocin receptor (OXTR) polymorphism (rs2254298) confer "vulnerability" for psychopathology or "differential susceptibility?" Insights from evolution. BMC Med. 10:38. doi:10.1186/1741-701510-38

Burghy, C. A., Stodola, D. E., Ruttle, P. L., Molloy, E. K., Armstrong, J. M., Oler, J. A., et al. (2012). Developmental pathways to amygdala-prefrontal function and internalizing symptoms in adolescence. Nat. Neurosci. 15, 1736-1741.

Champagne, F., Diorio, J., Sharma, S., and Meaney, M. J. (2001). Naturally occurring variations in maternal behavior in the rat are associated with differences in estrogeninducible central oxytocin receptors. Proc. Natl. Acad. Sci. U.S.A. 98, 12736-12741.

Champagne, F., and Meaney, M. J. (2001). Like mother, like daughter: evidence for non-genomic transmission of parental behavior and stress responsivity. Prog. Brain Res. 133, 287-302.

Champagne, F. A. (2008). Epigenetic mechanisms and the transgenerational effects of maternal care. Front. Neuroendocrinol. 29, 386-397.

Chen, F. S., Barth, M. E., Johnson, S L., Gotlib, I. H., and Johnson, S. C. (2011a). Oxytocin receptor (OXTR) polymorphisms and attachment in human infants. Front. Psychol. 2:200. doi:10.3389/fpsyg.2011.00200

Chen, F. S., Kumsta, R., von Dawans, B., Monakhov, M., Ebstein, R. P., and Heinrichs, M. (2011b). Common oxytocin receptor gene (OXTR) polymorphism and social support interact to reduce stress in humans. Proc. Natl. Acad. Sci. U.S.A. 108, 19937-19942.

Cho, M. M., DeVries, A. C., Williams, J. R., and Carter, C. S. (1999). The effects of oxytocin and vasopressin on partner preferences in male and female prairie voles (Microtus ochrogaster). Behav. Neurosci. 113, 1071-1079.

Choleris, E., Devidze, N., Kavaliers, M., and Pfaff, D. W. (2008). Steroidal/neuropeptide interactions in hypothalamus and amygdala related to social anxiety. Prog. Brain Res. 170, 291-303.

Cornelis, M. C., Glymour, M. M., Chang, S. C., Tchetgen, E. J., Liang, L., Koenen, K. C., et al. (2012). Oxytocin receptor (OXTR) is not associated with optimism in the Nurses' Health Study. Mol. Psychiatry 17, 1157-1159.

Cravchik, A., and Goldman, D. (2000). Neurochemical individuality: genetic diversity among human dopamine and serotonin receptors and transporters. Arch. Gen. Psychiatry 57, 1105-1114.

Cushing, B. S., and Kramer, K. M. (2005). Mechanisms underlying epigenetic effects of early social experience: the role of neuropeptides and steroids. Neurosci. Biobehav. Rev. 29, 1089-1105.

Dannlowski, U., Stuhrmann, A., Beutelmann, V., Zwanzger, P., Lenzen, T. Grotegerd, D., et al. (2012). Limbic scars: long-term consequences of childhood maltreatment revealed by functional and structural magnetic resonance imaging. Biol. Psychiatry 71, 286-293.

David, D. H., and Lyons-Ruth, K. (2005). Differential attachment responses of male and female infants to frightening maternal behavior: tend or befriend versus fight or flight? Infant Ment. Health J. 21, 1-18.
De Dreu, C. K., Greer, L. L., Handgraaf, M. J., Shalvi, S., Van Kleef, G. A., Baas, M., et al. (2010). The neuropeptide oxytocin regulates parochial altruism in intergroup conflict among humans. Science 328, 1408-1411.

De Dreu, C. K., Greer, L. L., Van Kleef, G. A., Shalvi, S., and Handgraaf, M. J. (2011). Oxytocin promotes human ethnocentrism. Proc. Natl. Acad. Sci. U.S.A. 108, 1262-1266.

De Dreu, C. K., Shalvi, S., Greer, L. L., Van Kleef, G. A., and Handgraaf, M. J. (2012). Oxytocin motivates non-cooperation in intergroup conflict to protect vulnerable in-group members. PLOS ONE 7:e46751. doi:10.1371/journal.pone.0046751

de Vries, G. J. (2008). Sex differences in vasopressin and oxytocin innervation of the brain. Prog. Brain Res. 170, 17-27.

Declerck, C. H., Boone, C., and Kiyonari, T. (2010). Oxytocin and cooperation under conditions of uncertainty: the modulating role of incentives and social information. Horm. Behav. 57, 368-374.

Delville, Y., Mansour, K. M., and Ferris, C. F. (1996). Testosterone facilitates aggression by modulating vasopressin receptors in the hypothalamus. Physiol. Behav. 60, 25-29.

Domes, G., Lischke, A., Berger, C. Grossmann, A., Hauenstein, K. Heinrichs, M., et al. (2010). Effects of intranasal oxytocin on emotional face processing in women. Psychoneuroendocrinology 35, 83-93.

Ebstein, R. P., Knafo, A., Mankuta, D. Chew, S. H., and Lai, P. S. (2012). The contributions of oxytocin and vasopressin pathway genes to human behavior. Horm. Behav. 61, 359-379.

Ebstein, R. P., Mankuta, D., Yirmiya, N., and Malavasi, F. (2011). Are retinoids potential therapeutic agents in disorders of social cognition including autism? FEBS Lett. 585, 1529-1536.

Feifel, D., MacDonald, K., McKinney, R., Heisserer, N., and Serrano, V. (2011). A randomized, placebo-controlled investigation of intranasal oxytocin in patients with anxiety. Neuropsychopharmacology 36, S324-S449.

Feifel, D., MacDonald, K., Nguyen, A., Cobb, P., Warlan, H., Galangue, B., et al. (2010). Adjunctive intranasal oxytocin reduces symptoms in schizophrenia patients. Biol. Psychiatry 68, 678-680.

Feldman, R. (2012). Oxytocin and social affiliation in humans. Horm. Behav. 61, 380-391.

Feldman, R., Zagoory-Sharon, O., Weisman, O., Schneiderman, I., Gordon,
I., Maoz, R., et al. (2012). Sensitive parenting is associated with plasma oxytocin and polymorphisms in the OXTR and CD38 genes. Biol. Psychiatry $72,175-181$

Furman, D. J., Chen, M. C., and Gotlib, I. H. (2011). Variant in oxytocin receptor gene is associated with amygdala volume. Psychoneuroendocrinology 36, 891-897.

Gabor, C. S., Phan, A., Clipperton-Allen, A. E., Kavaliers, M., and Choleris, E. (2012). Interplay of oxytocin, vasopressin, and sex hormones in the regulation of social recognition. Behav. Neurosci. 126, 97-109.

Gershon, E. S., Alliey-Rodriguez, N., and Liu, C. (2011). After GWAS: searching for genetic risk for schizophrenia and bipolar disorder. Am. J. Psychiatry 168, 253-256.

Gordon, I., Martin, C., Feldman, R., and Leckman, J. F. (2011). Oxytocin and social motivation. Dev. Cogn. Neurosci. 1, 471-493.

Gordon, I., Zagoory-Sharon, O., Leckman, J. F., and Feldman, R. (2010). Oxytocin and the development of parenting in humans. Biol. Psychiatry 68, 377-382.

Gunnar, M. R., and Quevedo, K. M. (2008). Early care experiences and HPA axis regulation in children: a mechanism for later trauma vulnerability. Prog. Brain Res. 167, 137-149.

Hamarman, S., Fossella, J., Ulger, C., Brimacombe, M., and Dermody, J. (2004). Dopamine receptor 4 (DRD4) 7-repeat allele predicts methylphenidate dose response in children with attention deficit hyperactivity disorder: a pharmacogenetic study. J. Child Adolesc. Psychopharmacol. 14, 564-574.

Hammock, E. A., and Young, L. J. (2006). Oxytocin, vasopressin and pair bonding: implications for autism. Philos. Trans. R. Soc. Lond. B Biol. Sci. 361, 2187-2198.

Heim, C., Young, L. J., Newport, D. J., Mletzko, T., Miller, A. H., and Nemeroff, C. B. (2009). Lower CSF oxytocin concentrations in women with a history of childhood abuse. Mol. Psychiatry 14, 954-958.

Higashida, H., Yokoyama, S., Huang, J. J., Liu, L., Ma, W. J., Akther, S., et al. (2012a). Social memory, amnesia, and autism: brain oxytocin secretion is regulated by $\mathrm{NAD}(+)$ metabolites and single nucleotide polymorphisms of CD38. Neurochem. Int. 61, 828-838.

Higashida, H., Yokoyama, S., Kikuchi, M., and Munesue, T. (2012b). CD38 and its role in oxytocin secretion and social behavior. Horm. Behav. 61, 351-358. 
Higashida, H., Yokoyama, S., Munesue, T., Kikuchi, M., Minabe, Y., and Lopatina, O. (2011). CD38 gene knockout juvenile mice: a model of oxytocin signal defects in autism. Biol. Pharm. Bull. 34, 1369-1372.

Holt-Lunstad, J., Birmingham, W., and Light, K. C. (2011). The influence of depressive symptomatology and perceived stress on plasma and salivary oxytocin before, during and after a support enhancement intervention. Psychoneuroendocrinology 36, 1249-1256.

Huffmeijer, R., Alink, L. R., Tops, M., Bakermans-Kranenburg, M. J., and van, I. M. H. (2012). Asymmetric frontal brain activity and parental rejection predict altruistic behavior: moderation of oxytocin effects. Cogn. Affect. Behav. Neurosci. 12, 382-392.

Huffmeijer, R., Tops, M., Alink, L. R., Bakermans-Kranenburg, M. J., and van Ijzendoorn, M. (2011). Love withdrawal is related to heightened processing of faces with emotional expressions and incongruent emotional feedback: evidence from ERPs. Biol. Psychol. 86, 307-313.

Hurlemann, R., Patin, A., Onur, O. A., Cohen, M. X., Baumgartner, T., Metzler, S., et al. (2010). Oxytocin enhances amygdala-dependent, socially reinforced learning and emotional empathy in humans. J. Neurosci. 30, 4999-5007.

Ihara, Y., and Aoki, K. (1999). Sexual selection by male choice in monogamous and polygynous human populations. Theor. Popul. Biol. 55, 77-93.

Inoue, H., Yamasue, H., Tochigi, M., Abe, O., Liu, X., Kawamura, Y., et al. (2010). Association between the oxytocin receptor gene and amygdalar volume in healthy adults. Biol. Psychiatry 68, 1066-1072.

Jack, A., Connelly, J. J., and Morris, J. P. (2012). DNA methylation of the oxytocin receptor gene predicts neural response to ambiguous social stimuli. Front. Hum. Neurosci. 6:280 doi:10.3389/fnhum.2012.00280

Jin, D., Liu, H. X., Hirai, H., Torashima, T., Nagai, T., Lopatina, O., et al. (2007). CD38 is critical for social behaviour by regulating oxytocin secretion. Nature 446, 41-45.

Johnson, A. E., Coirini, H., Insel, T. R., and McEwen, B. S. (1991). The regulation of oxytocin receptor binding in the ventromedial hypothalamic nucleus by testosterone and its metabolites. Endocrinology 128, 891-896.

Kim, H. S., Sherman, D. K., Sasaki, J. Y., Xu, J., Chu, T. Q., Ryu, C., et al. (2010). Culture, distress, and oxytocin receptor polymorphism (OXTR) interact to influence emotional support seeking. Proc. Natl. Acad. Sci. U.S.A. 107, 15717-15721.

Kiss, I., Levy-Gigi, E., and Keri, S. (2011). CD 38 expression, attachment style and habituation of arousal in relation to trust-related oxytocin release. Biol. Psychol. 88, 223-226.

Kumsta, R., and Heinrichs, M. (2012). Oxytocin, stress and social behavior: neurogenetics of the human oxytocin system. Curr. Opin. Neurobiol. doi: 10.1016/j.conb.2012.09.004. [Epub ahead of print].

Labuschagne, I., Phan, K. L., Wood, A., Angstadt, M., Chua, P., Heinrichs, M., et al. (2011). Medial frontal hyperactivity to sad faces in generalized social anxiety disorder and modulation by oxytocin. Int. J. Neuropsychopharmacol. 1-14.

Liu, J. C., Guastella, A. J., and Dadds, M. R. (2012). Effects of oxytocin on human social approach measured using intimacy equilibriums. Horm. Behav. 62, 585-591.

Loup, F., Tribollet, E., Dubois-Dauphin, M., and Dreifuss, J. J. (1991). Localization of high-affinity binding sites for oxytocin and vasopressin in the human brain. An autoradiographic study. Brain Res. 555, 220-232.

Loup, F., Tribollet, E., Dubois-Dauphin, M., Pizzolato, G., and Dreifuss, J. J. (1989). Localization of oxytocin binding sites in the human brainstem and upper spinal cord: an autoradiographic study. Brain Res. 500, 223-230.

Love, T. M., Enoch, M. A., Hodgkinson, C. A., Pecina, M., Mickey, B., Koeppe, R. A., et al. (2012). Oxytocin gene polymorphisms influence human dopaminergic function in a sex-dependent manner. Biol. Psychiatry 72, 198-206.

Lucht, M. J., Barnow, S., Sonnenfeld, C., Ulrich, I., Grabe, H. J., Schroeder, W., et al. (2012). Associations between the oxytocin receptor gene (OXTR) and "mind-reading" in humans-an exploratory study. Nord. J. Psychiatry. PMID:22809402. [Epub ahead of print].

Malhotra, A. K., Lencz, T., Correll, C. U., and Kane, J. M. (2007). Genomics and the future of pharmacotherapy in psychiatry. Int. Rev. Psychiatry 19, 523-530.

Marsh, A. A., Yu, H. H., Pine, D. S., Gorodetsky, E. K., Goldman, D., and Blair, R. J. (2012). The influence of oxytocin administration on responses to infant faces and potential moderation by OXTR genotype. Psychopharmacology 224 469-476.

McCrory, E., De Brito, S. A., and Viding, E. (2012). The link between child abuse and psychopathology: a review of neurobiological and genetic research. J. R. Soc. Med. 105, 151-156.

McMahon, F. J., Buervenich, S., Charney, D., Lipsky, R., Rush, A. J., Wilson, A. F., et al. (2006). Variation in the gene encoding the serotonin $2 \mathrm{~A}$ receptor is associated with outcome of antidepressant treatment. Am. J. Hum. Genet. 78, 804-814.

Meaney, M. J. (2001). Maternal care, gene expression, and the transmission of individual differences in stress reactivity across generations. Annu. Rev. Neurosci. 24, 1161-1192.

Modabbernia, A., Rezaei, F., Salehi, B., Jafarinia, M., Ashrafi, M., Tabrizi, M., et al. (2012). Intranasal oxytocin as an adjunct to risperidone in patients with schizophrenia: an 8-week, randomized, double-blind, placebo-controlled study. CNS Drugs. PMID:23233269. [Epub ahead of print].

Montag, C., Brockmann, E. M., Bayerl, M., Rujescu, D., Muller, D. J. and Gallinat, J. (2012). Oxytocin and oxytocin receptor gene polymorphisms and risk for schizophrenia: a case-control study. World J. Biol. Psychiatry. PMID:22651577. [Epub ahead of print]

Montag, C., Fiebach, C. J., Kirsch, P., and Reuter, M. (2011). Interaction of 5HTTLPR and a variation on the oxytocin receptor gene influences negative emotionality. Biol. Psychiatry 69 601-603.

Mrazek, D. A., Rush, A. J., Biernacka, J. M., O’Kane, D. J., Cunningham, J. M., Wieben, E. D., et al. (2009). SLC6A4 variation and citalopram response. Am. J. Med. Genet. B Neuropsychiatr. Genet. 150B, 341-351.

Munafo, M. R., Yalcin, B., Willis-Owen, S. A., and Flint, J. (2008). Association of the dopamine D4 receptor (DRD4) gene and approachrelated personality traits: metaanalysis and new data. Biol. Psychiatry 63, 197-206.

Naber, F., van Ijzendoorn, M. H. Deschamps, P., van Engeland, H., and Bakermans-Kranenburg, M. J. (2010). Intranasal oxytocin increases fathers' observed responsiveness during play with their children: a double-blind within-subject experiment. Psychoneuroendocrinology 35, 1583-1586.

Naber, F. B., Poslawsky, I. E., van Ijzendoorn, M. H., van Engeland,
H., and Bakermans-Kranenburg, M. J. (2012). Brief report: oxytocin enhances paternal sensitivity to a child with autism: a double-blind within-subject experiment with intranasally administered oxytocin. J. Autism Dev. Disord. doi: 10.1007/s10803-012-1536-6. [Epub ahead of print].

Neumann, I. D., and Landgraf, R. (2012). Balance of brain oxytocin and vasopressin: implications for anxiety, depression, and social behaviors. Trends Neurosci. 35, 649-659.

Norman, G. J., Hawkley, L., Luhmann, M., Ball, A. B., Cole, S. W., Berntson, G. G., et al. (2012). Variation in the oxytocin receptor gene influences neurocardiac reactivity to social stress and HPA function: a population based study. Horm. Behav. 61, 134-139.

O'Connell, G., Whalley, H. C., Mukherjee, P., Stanfield, A. C., Montag, C. Hall, J., et al. (2012). Association of genetic variation in the promoter region of OXTR with differences in social affective neural processing. $J$. Behav. Brain Sci. 2, 60-66.

Ophir, A. G., Gessel, A., Zheng, D. J., and Phelps, S. M. (2012). Oxytocin receptor density is associated with male mating tactics and social monogamy. Horm. Behav. 61, 445-453.

Ozsoy, S., Esel, E., and Kula, M. (2009). Serum oxytocin levels in patients with depression and the effects of gender and antidepressant treatment. Psychiatry Res. 169, 249-252.

Patisaul, H. B., Scordalakes, E. M., Young, L. J., and Rissman, E. F. (2003). Oxytocin, but not oxytocin receptor, is regulated by oestrogen receptor beta in the female mouse hypothalamus. J. Neuroendocrinol. 15, 787-793.

Pedersen, C. A., Gibson, C. M., Rau, S. W., Salimi, K., Smedley, K. L., Casey, R. L., et al. (2011). Intranasal oxytocin reduces psychotic symptoms and improves Theory of Mind and social perception in schizophrenia. Schizophr. Res. 132, 50-53.

Pierrehumbert, B., Torrisi, R., Ansermet, F., Borghini, A., and Halfon, O. (2012). Adult attachment representations predict cortisol and oxytocin responses to stress. Attach. Hum. Dev. 14, 453-476.

Read, J., and Hammersley, P. (2005). Child sexual abuse and schizophrenia. Br. J. Psychiatry 186, 76; author reply 76.

Riebold, M., Mankuta, D., Lerer, E., Israel, S., Zhong, S., Nemanov, L., 
et al. (2011). All-trans retinoic acid upregulates reduced CD38 transcription in lymphoblastoid cell lines from Autism spectrum disorder. Mol. Med. 17, 799-806.

Rodrigues, S. M., Saslow, L. R., Garcia, N., John, O. P., and Keltner, D. (2009). Oxytocin receptor genetic variation relates to empathy and stress reactivity in humans. Proc. Natl. Acad. Sci. U.S.A. 106, 21437-21441.

Ross, H. E., Freeman, S. M., Spiegel, L. L., Ren, X., Terwilliger, E. F., and Young, L. J. (2009). Variation in oxytocin receptor density in the nucleus accumbens has differential effects on affiliative behaviors in monogamous and polygamous voles. J. Neurosci. 29, 1312-1318.

Rubin, L. H., Carter, C. S., Drogos, L., Jamadar, R., Pournajafi-Nazarloo, H., Sweeney, J. A., et al. (2011). Sex-specific associations between peripheral oxytocin and emotion perception in schizophrenia. Schizophr. Res. 130, 266-270.

Rubin, L. H., Carter, C. S., Drogos, L., Pournajafi-Nazarloo, H., Sweeney, J. A., and Maki, P. M. (2010). Peripheral oxytocin is associated with reduced symptom severity in schizophrenia. Schizophr. Res. 124, 13-21.

Rupp, H. A., James, T. W., Ketterson, E. D., Sengelaub, D. R., Ditzen, B., and Heiman, J. R. (2012). Amygdala response to negative images in postpartum versus nulliparous women and intranasal oxytocin. Soc. Cogn. Affect. Neurosci. PMID:22956670. [Epub ahead of print].

Salonia, A., Nappi, R. E., Pontillo, M., Daverio, R., Smeraldi, A., Briganti, A., et al. (2005). Menstrual cyclerelated changes in plasma oxytocin are relevant to normal sexual function in healthy women. Horm. Behav. 47, 164-169.

Saphire-Bernstein, S., Way, B. M., Kim, H. S., Sherman, D. K., and Taylor, S. E. (2011). Oxytocin receptor gene (OXTR) is related to psychological resources. Proc. Natl. Acad. Sci. U.S.A. 108, 15118-15122.

Sauer, C., Montag, C., Worner, C., Kirsch, P., and Reuter, M. (2012). Effects of a common variant in the CD38 gene on social processing in an oxytocin challenge study: possible links to autism. Neuropsychopharmacology 37, 1474-1482.

Saveanu, R. V., and Nemeroff, C. B. (2012). Etiology of depression: genetic and environmental factors. Psychiatr. Clin. North Am. 35, 51-71.
Scheele, D., Striepens, N., Gunturkun, O., Deutschlander, S., Maier, W. Kendrick, K. M., et al. (2012). Oxytocin modulates social distance between males and females. J. Neurosci. 32, 16074-16079.

Shamay-Tsoory, S. G., Fischer, M., Dvash, J., Harari, H., PerachBloom, N., and Levkovitz, Y. (2009). Intranasal administration of oxytocin increases envy and schadenfreude (gloating). Biol. Psychiatry 66 864-870.

Simeon, D., Bartz, J., Hamilton, H., Crystal, S., Braun, A., Ketay, S., et al. (2011). Oxytocin administration attenuates stress reactivity in borderline personality disorder: a pilot study. Psychoneuroendocrinology 36, 1418-1421.

Slattery, D. A., and Neumann, I. (2010). Oxytocin and major depressive disorder: experimental and clinical evidence for links to aetiology and possible treatment. Pharmaceuticals 3, 702-724.

Smeets, T., Dziobek, I., and Wolf, O. T. (2009). Social cognition under stress: differential effects of stress-induced cortisol elevations in healthy young men and women. Horm. Behav. 55, 507-513.

Smith, A. L., Freeman, S. M., Stehouwer, J. S., Inoue, K., Voll, R. J., Young, L. J., et al. (2012a). Synthesis and evaluation of C-11, F-18 and I-125 small molecule radioligands for detecting oxytocin receptors. Bioorg. Med. Chem. 20, 2721-2738.

Smith, T. W., Uchino, B. N., Mackenzie, J., Hicks, A., Campo, R. A., Reblin, M., et al. (2012b). Effects of couple interactions and relationship quality on plasma oxytocin and cardiovascular reactivity: empirical findings and methodological considerations. Int. J. Psychophysiol. doi:10.1016/j.ijpsycho.2012.04.006. [Epub ahead of print]

Sripada, C. S., Phan, K. L., Labuschagne, I., Welsh, R., Nathan, P. J., and Wood, A. G. (2012). Oxytocin enhances resting-state connectivity between amygdala and medial frontal cortex. Int. J. Neuropsychopharmacol. doi:10.1017/S1461145712000533. [Epub ahead of print].

Stankova, T., Eichhammer, P., Langguth, B., and Sand, P. G. (2012). Sexually dimorphic effects of oxytocin receptor gene (OXTR) variants on Harm Avoidance. Biol. Sex Differ. 3, 17.

Stolzenberg, D. S., Stevens, J. S., and Rissman, E. F. (2012). Experiencefacilitated improvements in pup retrieval; evidence for an epigenetic effect. Horm. Behav. 62, 128-135.
Strathearn, L., Fonagy, P., Amico, J., and Montague, P. R. (2009). Adult attachment predicts maternal brain and oxytocin response to infant cues. Neuropsychopharmacology 34 2655-2666.

Strathearn, L., Iyengar, U., Fonagy, P., and Kim, S. (2012). Maternal oxytocin response during motherinfant interaction: associations with adult temperament. Horm. Behav. 61, 429-435.

Szeto, A., McCabe, P. M., Nation, D. A., Tabak, B. A., Rossetti, M. A. McCullough, M. E., et al. (2011). Evaluation of enzyme immunoassay and radioimmunoassay methods for the measurement of plasma oxytocin. Psychosom. Med. 73 393-400.

Tansey, K. E., Brookes, K. J., Hill, M. J., Cochrane, L. E., Gill, M., Skuse, D., et al. (2010). Oxytocin receptor (OXTR) does not play a major role in the aetiology of autism: genetic and molecular studies. Neurosci. Lett. 474, 163-167.

Taylor, S. E., Klein, L. C., Lewis, B. P., Gruenewald, T. L., Gurung, R. A., and Updegraff, J. A. (2000). Biobehavioral responses to stress in females: tend-and-befriend, not fight-or-flight. Psychol. Rev. 107, 411-429.

Teicher, M. H., Anderson, C. M. and Polcari, A. (2012). Childhood maltreatment is associated with reduced volume in the hippocampal subfields CA3, dentate gyrus, and subiculum. Proc. Natl. Acad. Sci. U.S.A. 109, E563-E572.

Teltsh, O., Kanyas-Sarner, K., Rigbi, A., Greenbaum, L., Lerer, B., and Kohn, Y. (2011). Oxytocin and vasopressin genes are significantly associated with schizophrenia in a large Arab-Israeli pedigree. Int. J. Nneuropsychopharmacol. $1-11$.

Thompson, R. J., Parker, K. J., Hallmayer, J. F., Waugh, C. E., and Gotlib, I. H. (2011). Oxytocin receptor gene polymorphism (rs2254298) interacts with familial risk for psychopathology to predict symptoms of depression and anxiety in adolescent girls. Psychoneuroendocrinology 36, 144-147.

Tost, H., Kolachana, B., Hakimi, S., Lemaitre, H., Verchinski, B. A. Mattay, V. S., et al. (2010). A common allele in the oxytocin receptor gene (OXTR) impacts prosocial temperament and human hypothalamic-limbic structure and function. Proc. Natl. Acad. Sci. U.S.A. 107, 13936-13941.
Unternaehrer, E., Luers, P., Mill, J., Dempster, E., Meyer, A. H., Staehli, S., et al. (2012). Dynamic changes in DNA methylation of stressassociated genes (OXTR, BDNF) after acute psychosocial stress. Transl. Psychiatry 2, e150.

van Anders, S. M., Goldey, K. L., and Kuo, P. X. (2011). The Steroid/Peptide Theory of Social Bonds: integrating testosterone and peptide responses for classifying social behavioral contexts. Psychoneuroendocrinology 36, 1265-1275.

van Honk, J., and Schutter, D. J. (2007). Testosterone reduces conscious detection of signals serving social correction: implications for antisocial behavior. Psychol. Sci. 18, 663-667.

van Ijzendoorn, M. H., Belsky, J., and Bakermans-Kranenburg, M. J. (2012). Serotonin transporter genotype 5HTTLPR as a marker of differential susceptibility? A meta-analysis of child and adolescent gene-byenvironment studies. Transl. Psychiatry 2, e147.

van Ijzendoorn, M. H., Huffmeijer, R., Alink, L. R., BakermansKranenburg, M. J., and Tops, M. (2011). The Impact of oxytocin administration on charitable donating is moderated by experiences of parental love-withdrawal. Front. Psychol. 2:258. doi:10.3389/fpsyg.2011.00258

van Os, J., Kenis, G., and Rutten, B. P. (2010). The environment and schizophrenia. Nature 468, 203-212.

Van Vugt, M. (2009). Sex differences in intergroup competition, aggression, and warfare: the male warrior hypothesis. Ann. N. Y. Acad. Sci. 1167, 124-134.

Walter, N. T., Montag, C., Markett, S., Felten, A., Voigt, G., and Reuter, M. (2012). Ignorance is no excuse: moral judgments are influenced by a genetic variation on the oxytocin receptor gene. Brain Cogn. 78, 268-273.

Walum, H., Lichtenstein, P., Neiderhiser, J. M., Reiss, D., Ganiban, J. M., Spotts, E. L., et al. (2012). Variation in the oxytocin receptor gene is associated with pair-bonding and social behavior. Biol. Psychiatry 71, 419-426.

Walum, H., Westberg, L., Henningsson, S., Neiderhiser, J. M., Reiss, D. Igl, W., et al. (2008). Genetic variation in the vasopressin receptor 1a gene (AVPR1A) associates with pair-bonding behavior in humans. Proc. Natl. Acad. Sci. U.S.A. 105, 14153-14156. 
Weisman, O., Zagoory-Sharon, O., and Feldman, R. (2012a). Oxytocin administration to parent enhances infant physiological and behavioral readiness for social engagement. Biol. Psychiatry 72, 982-989.

Weisman, O., Zagoory-Sharon, O., Schneiderman, I., Gordon, I., and Feldman, R. (2012b). Plasma oxytocin distributions in a large cohort of women and men and their gender-specific associations with anxiety. Psycho neuroendocrinology.

doi: 10.1016/j.psyneuen.2012.08.011. [Epub ahead of print].

Williams, J. R., Insel, T. R., Harbaugh, C. R., and Carter, C. S. (1994). Oxytocin administered centrally facilitates formation of a partner preference in female prairie voles (Microtus ochrogaster). J. Neuroendocrinol. 6, 247-250.
Windle, R. J., Gamble, L. E., Kershaw, Y. M., Wood, S. A., Lightman, S. L., and Ingram, C. D. (2006). Gonadal steroid modulation of stress-induced hypothalamopituitary-adrenal activity and anxiety behavior: role of central oxytocin. Endocrinology 147, 2423-2431.

Wu, N., Li, Z., and Su, Y. (2012). The association between oxytocin receptor gene polymorphism (OXTR) and trait empathy. J. Affect. Disord. 138, 468-472.

Yamasue, H., Yee, J. R., Hurlemann, R. Rilling, J. K., Chen, F. S., MeyerLindenberg, A., et al. (2012). Integrative approaches utilizing oxytocin to enhance prosocial behavior: from animal and human social behavior to autistic social dysfunction. $J$. Neurosci. 32, 14109-14117.

Zak, P. J., Kurzban, R., Ahmadi, S., Swerdloff, R. S., Park,
J., Efremidze, L., et al. (2009). Testosterone administration decreases generosity in the ultimatum game. PLoS ONE 4:e8330. doi:10.1371/journal.pone.0008330

Zhang, J. P., Lencz, T., and Malhotra, A. K. (2010). D2 receptor genetic variation and clinical response to antipsychotic drug treatment: a metaanalysis. Am. J. Psychiatry 167, 763-772.

Zhong, S., Monakhov, M., Mok, H. P., Tong, T., Lai, P. S., Chew S. H., et al. (2012). U-shaped relation between plasma oxytocin levels and behavior in the trust game. PLoS ONE 7:e51095. doi:10.1371/journal.pone.0051095

Conflict of Interest Statement: The author declares that the research was conducted in the absence of any commercial or financial relationships that could be construed as a potential conflict of interest.

Received: 05 December 2012; paper pending published: 18 December 2012; accepted: 20 December 2012; published online: 10 January 2013.

Citation: MacDonald KS (2013) Sex receptors, and attachment: a review of individual factors influencing response to oxytocin. Front. Neurosci. 6:194. doi: 10.3389/fnins.2012.00194

This article was submitted to Frontiers in Neuroendocrine Science, a specialty of Frontiers in Neuroscience.

Copyright $\odot 2013$ MacDonald. This is an open-access article distributed under the terms of the Creative Commons Attribution License, which permits use, distribution and reproduction in other forums, provided the original authors and source are credited and subject to any copyright notices concerning any third-party graphics etc. 